\title{
Statistical Analyses of the Effects of Welding Processes on Load, Extension and Hardness Properties of Welded Mild Steel Plates
}

\author{
Dayo Hephzibah Oladebeye ${ }^{1}$, Samuel Babatope Adejuyigbe ${ }^{2}$ and Biliyaminu Kareem ${ }^{3}$ \\ 1. Department of Mechanical Engineering Technology, Federal Polytechnic, Ado-Ekiti 360231, Ekiti State, Nigeria \\ 2. Mechatronics Engineering Department, Federal University, Oye-Ekiti 374101, Ekiti State, Nigeria \\ 3. Industrial and Production Engineering Department, Federal University of Technology, Akure 340001, Ondo State, Nigeria
}

\begin{abstract}
Mild steel plates of thicknesses $0.5 \mathrm{~mm}, 0.6 \mathrm{~mm}, 0.7 \mathrm{~mm}, 0.8 \mathrm{~mm}, 0.9 \mathrm{~mm}$ and $1.0 \mathrm{~mm}$ were prepared as test samples. After welding with the developed welding robot and manual electric arc welding machine these test samples were subjected to Tensile Strength and Hardness tests. All data obtained including hardness, load and extension were analyzed and the data produced from electric arc welding operations, the robot welding operations and un-welded plates (control) were compared with one another. The statistical analyses of hardness, load and extension tests for developed welding robot, manual electric arc welding and un-welded (control) mild steel plates of different thicknesses were carried out. The results revealed that for hardness, the developed robot welding has the highest mean value of 115.30, standard deviation value of 14.32 and variance value of 205.06. The descriptive statistics of the load showed that the developed robot welding samples collectively have the lowest mean value of 2,536.85, standard deviation value of 704.21 and variance value of 495,911.72. The descriptive statistics of the extension in which the developed robot welding samples collectively have the lowest mean value of 1.29 , standard deviation value of 0.43 and variance value of 0.18 were also determined. The result for hardness showed homogeneity of variance among hardness tests of the samples, which implies variation in the hardness test among the tests of the samples since $p$-value is 0.038 . While the result for loads shows homogeneity of variance among loads of the samples in which the result reveals that there is no variation in the loads among the tests of the samples since $p$-value is 0.322 . The result for extension shows homogeneity of variance among extensions of the samples in which it revealed that there is variation in the extensions among the tests of the samples since $p$-value is 0.011 . The analysis of variance (ANOVA) test result revealed that there is a significant difference in the hardness of the samples in which developed robot welding operation gave the highest hardness compared with electric arc welding and un-welded (CONTROL) since $p$-value is 0.028. The ANOVA test result for load revealed that there is no significant difference in the loads of the samples since $p$-value is 0.51 . The ANOVA test result of the extension shows that there is a significant difference in the extension of the samples in which developed robot welding operation gave the lowest extension compared with electric arc welding and un-welded (CONTROL) since $p$-value is 0.001 . The results of hardness also showed the mean difference of 16.48 between developed robot welding and un-welded (CONTROL) samples and 7.26 between developed robot welding and electric arc welding samples. Finally, for extension the mean difference of -5.28 between developed robot welding and un-welded (CONTROL) samples and -1.22 between developed robot welding and electric arc welding samples were established.
\end{abstract}

Key words: Statistical analysis, welding processes, load, extension, hardness, mild steel.

\section{Introduction}

Statistics is a research division concerned with gathering, arranging and analyzing data and drawing inferences from the samples to the whole population [1]. This includes careful study design, careful selection

Corresponding author: Dayo Hephzibah Oladebeye, Ph.D., professor, research field: mechanical engineering. of the research sample and selection of an effective statistical test. Adequate statistical knowledge is important for the proper design of an epidemiological study or a clinical trial. Improper statistical approaches can lead to false conclusions that can lead to unethical behavior [2]. Variable is a characteristic which differs from one member of the population to 
another [3]. Variables such as height and weight are measured by some kind of scale, conveying quantitative details and being called quantitative variables. Sex and the color of the eyes provide qualitative information and are called quality variables [3].

Product joining is one of the most critical criteria for fabrication and assembly operations. Joining, whether permanent or temporary, also becomes the technical finishing activity prior to shipping a product. Efficiency in the joining process and common quality may affect the economy of production significantly. Importantly, joining techniques and operating parameters vary widely with various materials to be joined and the required consistency of the joint. Stainless steel (SS-316) and mild steel (MS) are among the components most commonly used in a variety of applications. Their unlike welds are commonly used in pressure vessels, boilers, vessel building, power generation heat exchangers and petrochemical plants [4]. There are, however, a range of problems in welding dissimilar welds, such as solidification cracking, hydrogen cracking and the formation of brittle intermetallic materials, leading to weld failure before the planned design life [5]. The selection of filler material within the dissimilar joining material is also very important.

Welding therefore involves a wide range of scientific variables, such as time, temperature, electrode, input power and weld speed [6-9]. As a joining process, the benefits of welding include high joint strength, easy deployment, flexibility and low manufacturing costs [10]. Any weld design shall aim to ensure integrity of the weld and will effectively weld defects. Mohammed et al. [11] used the process of shielded metal arc welding (SMAW) to investigate the mechanical and metallurgical properties of medium carbon steel with respect to weld metal, heat-affected region and parent metal. From the results, the SMAW of medium carbon steel increased the strength of the welded joint, in particular the heat-affected zone (HAZ), as shown by lower impact strength, higher tensile strength than the parent and welded metal attributed to the fine ferrite matrix and fine pearlite distribution compared to the weld and parent metal. However, there was a loss of ductility in the welded joint which caused the material to become brittle. Talabi et al. [12] addressed the effect of welding variables on the mechanical properties of a low carbon steel plate $10 \mathrm{~mm}$ thick welded using the SMAW technique. Soldering current, arc voltage, welding speed and electrode diameter were the examined welding parameters. The welded samples were cut and machined to specifications for standard tensile, impact toughness, and hardness testing. The results demonstrated that the parameters chosen for welding had important effects on the mechanical properties of the welded samples. Increases in arc voltage and welding current increased hardness and decreased yield strength, tensile strength and durability of result. Increasing the welding speed from 40-66.67 $\mathrm{mm} / \mathrm{min}$ resulted in improved hardness characteristics of the welded samples. Initial decrease in tensile strength and yield was observed which subsequently increased as the welding speed increased. This research work focuses on statistically evaluating and assessing the impact of welding processes on the charging, extension and hardness properties of welded mild steel plates.

\section{Instruments Deployed for the Experiments}

As shown in Plates 1 and 2 [13], the following instruments were deployed to conduct experiments of mechanical properties on the welded and unwelded mild steel plates of different thickness. 


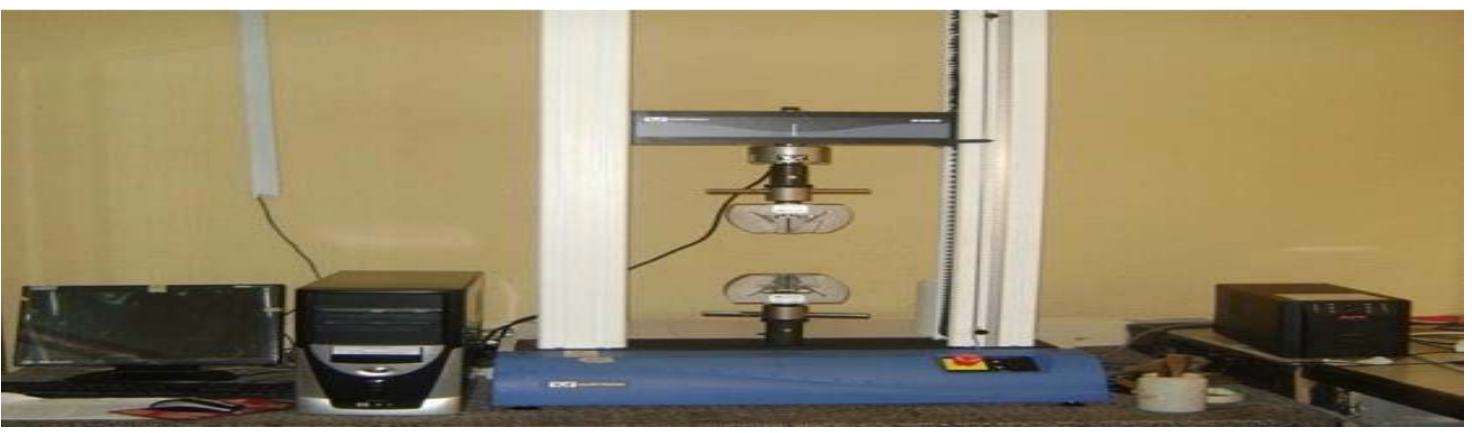

Plate 1 Universal Instron machine, model 3369, maker (Instron).

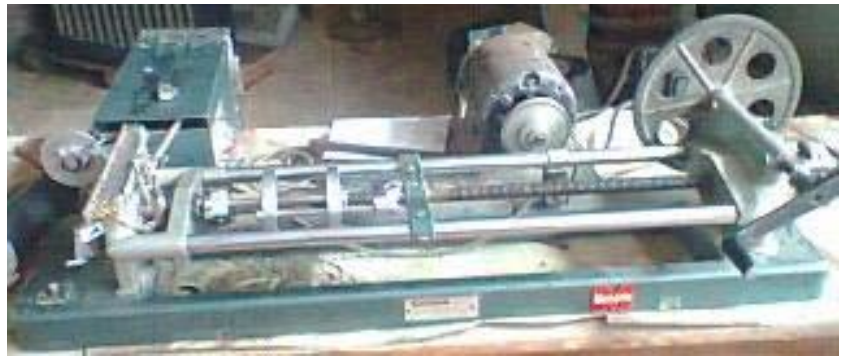

Plate 2 Brinell hardness testing machine.

\section{Tensile Strength Test on Different} Thicknesses of Mild Steel Plate Specimens with Manual, Developed and without Welding Operation (CONTROL)

The results and analyses of the tensile strength test of welded and un-welded mild steel plates showing the effects of welding processes on load and extension for different thicknesses are shown in Table 1.

Fig. 1 shows variation in load on welded and un-welded mild steel plates (specimens) of different sizes in which $1.0 \mathrm{~mm}$ mild steel plate without welding (CONTROL Sample) gave the highest load impact. For developed robot welding Sample $0.8 \mathrm{~mm}$ gave the highest. For electric arc welding, Sample 1.0 $\mathrm{mm}$ gave the highest. The chart reveals that Sample $1.0 \mathrm{~mm}$ without welding gave the overall highest load impact. The three sets of samples showed fair trend of increase in load impact with increasing thickness of mild steel plate.

Fig. 2 shows variation in extension of welded and un-welded mild steel plates (specimens) of different sizes in which the un-welded (CONTROL) samples gave the highest extension. Developed robot welding samples gave the lowest. This may be attributed to their comparatively higher hardness values over the electric arc welding and CONTROL values as discussed in Fig. 3 below.

Table 1 Tensile test on different thicknesses of mild steel plate specimens with manual arc welding, developed robot welding operations and without welding operation (control).

\begin{tabular}{|c|c|c|c|c|c|c|}
\hline \multirow{2}{*}{ Specimen/gauge (mm) } & Load $(\mathrm{N})$ & Extension (mm) & Load $(\mathrm{N})$ & Extension (mm) & Load $(\mathrm{N})$ & Extension (mm) \\
\hline & \multicolumn{2}{|c|}{ Control } & \multicolumn{2}{|c|}{ Robot welded } & \multicolumn{2}{|c|}{ Manually welded } \\
\hline 0.5 & $1,595.27883$ & 2.86669 & $2,051.187$ & 1.316848 & $1,094.833536$ & 1.521686 \\
\hline 0.6 & $2,344.70200$ & 5.36669 & $1,372.938$ & 1.171948 & $2,070.12609$ & 2.6867 \\
\hline 0.7 & 2,802.22949 & 5.60000 & $2,573.213$ & 1.016686 & $2,010.03127$ & 1.766662 \\
\hline 0.8 & $3,403.11117$ & 8.53337 & $3,188.307$ & 1.68355 & 2,847.31429 & 4.273364 \\
\hline 0.9 & 4,309.11109 & 7.16669 & 2,997.6339 & 0.670048 & 3,749.99195 & 2.513364 \\
\hline 1.0 & $4,863.79825$ & 9.86669 & $3,037.786$ & 1.850236 & $4,195.0275$ & 2.27515 \\
\hline
\end{tabular}




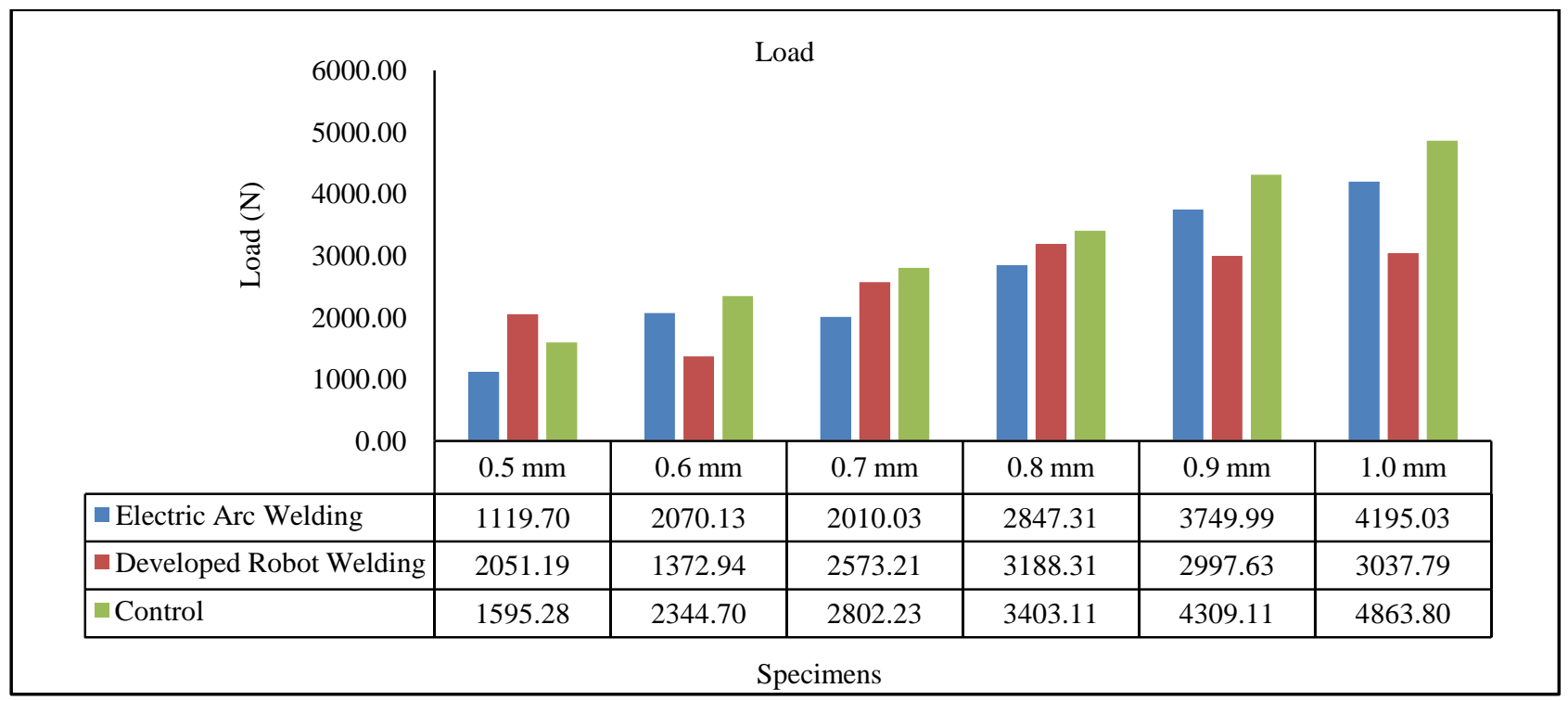

Fig. 1 Load on welded and un-welded mild steel plate specimen for the tensile strength test.

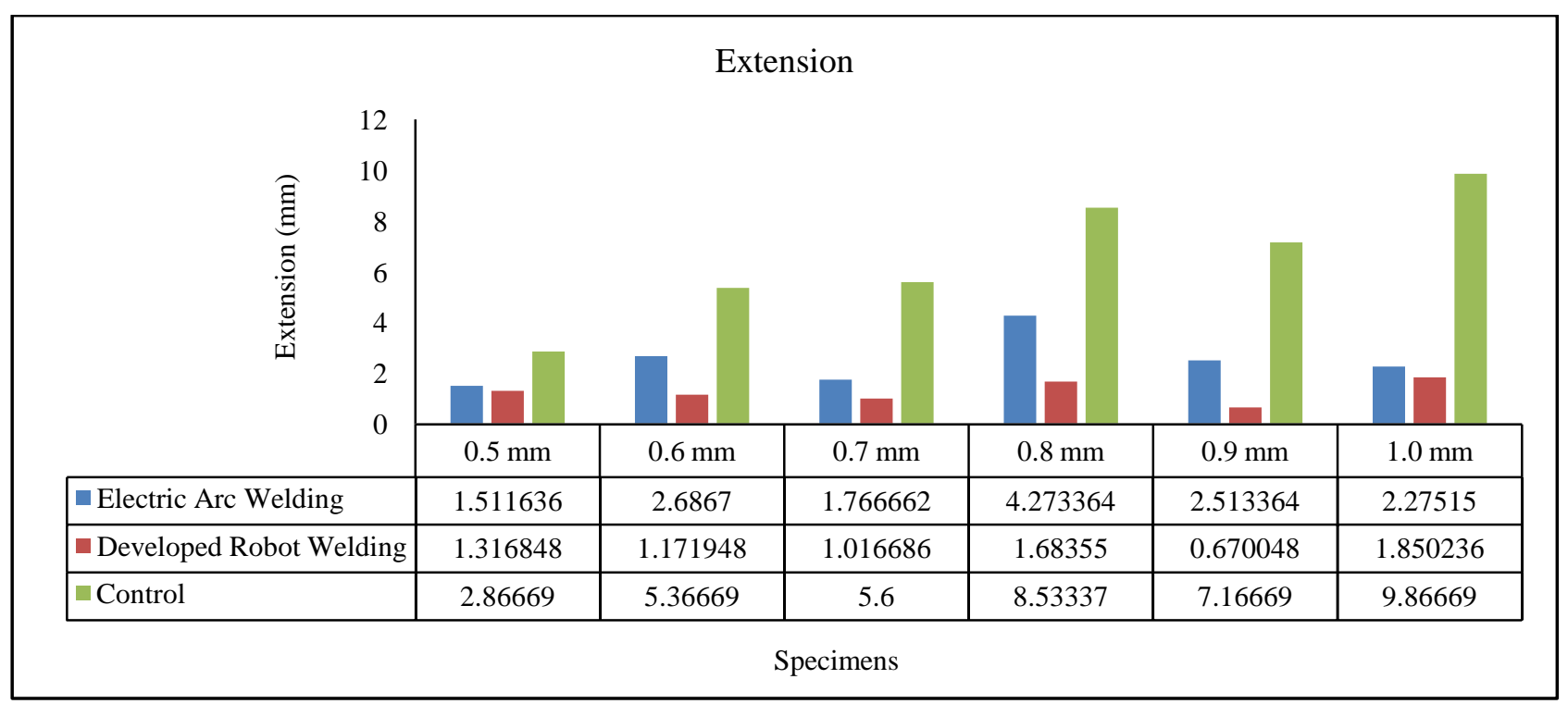

Fig. 2 Extension of welded and un-welded mild steel plate specimen for the tensile strength test.

\subsection{Hardness Test of Welded Mild Steel Plate with Developed Welding Robot}

The results and analyses of the hardness tests of welded mild steel plates for different thicknesses using developed welding robot are shown in Table 2.

\subsection{Hardness Test of Welded Mild Steel Plate with Electric Arc Welding (Manual)}

The results and analyses of the hardness tests of welded mild steel plates for different thicknesses using electric arc welding are shown in Table 3.
3.3 Hardness Test on Different Thicknesses of Mild Steel Plate Specimens without Welding Operation (CONTROL)

The results and analyses of the hardness test of un-welded mild steel plates for different thickness without welding operation, which serves as control specimens are shown in Table 4.

Fig. 3 shows variation in hardness values of welded and un-welded mild steel plates (specimens) of different sizes in which the developed robot welding samples have the highest hardness. 
Properties of Welded Mild Steel Plates

Table 2 Hardness test on welded mild plates using developed welding robot.

\begin{tabular}{|c|c|c|c|c|c|}
\hline \multicolumn{6}{|c|}{ Hardness test on the developed welding robot } \\
\hline \multicolumn{6}{|c|}{$0.5 \mathrm{~mm}$ mild steel plate specimen } \\
\hline \multirow{2}{*}{ Number of test } & \multicolumn{5}{|c|}{ Samples } \\
\hline & $\mathrm{A}$ & $\mathrm{B}$ & $\mathrm{C}$ & $\mathrm{D}$ & $\mathrm{E}$ \\
\hline 1 & 147 & 149 & 146 & 158 & 157 \\
\hline 2 & 143 & 146 & 143 & 156 & 156 \\
\hline 3 & 143 & 143 & 143 & 143 & 131 \\
\hline 4 & 131 & 143 & 143 & 143 & 128 \\
\hline 5 & 121 & 144 & 131 & 131 & 121 \\
\hline 6 & 118 & 143 & 128 & 143 & 143 \\
\hline AVG & 133.83 & 144.67 & 139.00 & 145.67 & 139.33 \\
\hline SD & 11.29 & 2.21 & 6.86 & 9.09 & 13.77 \\
\hline $\mathrm{SE}$ & 4.61 & 0.90 & 2.80 & 3.71 & 5.62 \\
\hline \multicolumn{6}{|c|}{$0.6 \mathrm{~mm}$ mild steel plate specimen } \\
\hline 1 & 111 & 95.5 & 147 & 95.5 & 111 \\
\hline 2 & 143 & 111 & 143 & 143 & 121 \\
\hline 3 & 143 & 121 & 111 & 111 & 95.5 \\
\hline 4 & 111 & 103 & 103 & 103 & 95.5 \\
\hline 5 & 111 & 111 & 103 & 111 & 95.5 \\
\hline 6 & 95.5 & 95.5 & 95.5 & 103 & 94.3 \\
\hline AVG & 119.08 & 106.17 & 117.08 & 111.08 & 102.13 \\
\hline SD & 17.78 & 9.17 & 20.27 & 15.23 & 10.23 \\
\hline$\underline{\mathrm{SE}}$ & 7.26 & 3.74 & 8.28 & 6.22 & 4.18 \\
\hline \multicolumn{6}{|c|}{$0.7 \mathrm{~mm}$ mild steel plate specimen } \\
\hline 1 & 135 & 137 & 120 & 145 & 116 \\
\hline 2 & 131 & 131 & 111 & 143 & 111 \\
\hline 3 & 121 & 95.5 & 95.5 & 95.5 & 111 \\
\hline 4 & 103 & 95.5 & 95.5 & 95.5 & 111 \\
\hline 5 & 95.5 & 95.5 & 95.5 & 94.3 & 103 \\
\hline 6 & 94.2 & 95.5 & 103 & 94.1 & 102 \\
\hline AVG & 113.28 & 108.33 & 103.42 & 111.23 & 109.00 \\
\hline SD & 16.49 & 18.23 & 9.32 & 23.18 & 4.93 \\
\hline $\mathrm{SE}$ & 6.73 & 7.44 & 3.80 & 9.46 & 2.01 \\
\hline \multicolumn{6}{|c|}{$0.8 \mathrm{~mm}$ mild steel plate specimen } \\
\hline 1 & 111 & 115 & 95.5 & 103 & 95.5 \\
\hline 2 & 121 & 111 & 121 & 103 & 95.5 \\
\hline 3 & 95.5 & 111 & 131 & 95.5 & 95.6 \\
\hline 4 & 95.5 & 103 & 95.5 & 111 & 95.5 \\
\hline 5 & 121 & 95.5 & 95.5 & 121 & 94.5 \\
\hline 6 & 95.5 & 95.5 & 95.5 & 95.5 & 94.3 \\
\hline AVG & 106.58 & 105.17 & 105.67 & 104.83 & 95.15 \\
\hline SD & 11.57 & 7.71 & 14.66 & 8.95 & 0.53 \\
\hline $\mathrm{SE}$ & 4.72 & 3.15 & 5.99 & 3.65 & 0.22 \\
\hline \multicolumn{6}{|c|}{$0.9 \mathrm{~mm}$ mild steel plate specimen } \\
\hline 1 & 102 & 111 & & 137 & 117 \\
\hline 2 & 96.5 & 103 & & 131 & 111 \\
\hline 3 & 95.5 & 95.5 & 95.5 & 111 & 103 \\
\hline 4 & 95.5 & 94.7 & 95.5 & 103 & 103 \\
\hline
\end{tabular}


Table 2 to be continued

\begin{tabular}{llllll}
\hline 5 & 95.7 & 94.8 & 95.5 & 103 & 121 \\
6 & 95.5 & 94.5 & 103 & 95.5 & 121 \\
AVG & 96.78 & 98.92 & 97.38 & 113.42 & 112.67 \\
SD & 2.36 & 6.17 & 3.25 & 15.33 & 7.61 \\
SE & 0.96 & 2.52 & 1.33 & 6.26 & 3.11 \\
\hline 1.0 mm mild steel plate specimen & & & 146 & 108 \\
\hline 1 & 143 & 144 & 111 & 143 & 103 \\
2 & 143 & 143 & 143 & 143 & 121 \\
3 & 131 & 121 & 121 & 156 & 131 \\
4 & 103 & 103 & 121 & 143 & 121 \\
5 & 95.5 & 121 & 121 & 95.5 & 117.50 \\
6 & 103 & 111 & 95.5 & 137.75 & 9.31 \\
AVG & 119.75 & 123.83 & 118.75 & 19.45 & 3.80 \\
SD & 19.82 & 15.21 & 14.16 & 7.94 & \\
SE & 8.09 & 6.21 & 5.78 & & \\
\hline
\end{tabular}

Table 3 Hardness test on welded mild plates using electric arc welding (manual).

\begin{tabular}{|c|c|c|c|c|c|}
\hline \multicolumn{6}{|c|}{ Hardness test on manual welding test } \\
\hline \multicolumn{6}{|c|}{$0.5 \mathrm{~mm}$ mild steel plate specimen } \\
\hline \multirow{2}{*}{ Number of test } & \multicolumn{5}{|c|}{ Samples } \\
\hline & A & $\mathrm{B}$ & $\mathrm{C}$ & $\mathrm{D}$ & $\mathrm{E}$ \\
\hline 1 & 143 & 121 & 118 & 106 & 95.5 \\
\hline 2 & 121 & 95.5 & 95.5 & 111 & 121 \\
\hline 3 & 120 & 95.5 & 98 & 131 & 95.5 \\
\hline 4 & 118 & 103 & 103 & 121 & 95.5 \\
\hline 5 & 115 & 100 & 95.5 & 121 & 95.5 \\
\hline 6 & 111 & 95.5 & 95.5 & 121 & 95.5 \\
\hline AVG & 121.33 & 101.75 & 100.92 & 118.50 & 99.75 \\
\hline SD & 10.24 & 9.06 & 8.09 & 8.04 & 9.50 \\
\hline SE & 4.18 & 3.70 & 3.30 & 3.28 & 3.88 \\
\hline \multicolumn{6}{|c|}{$0.6 \mathrm{~mm}$ mild steel plate specimen } \\
\hline 1 & 143 & 103 & 95.5 & 103 & 95.5 \\
\hline 2 & 130 & 95.5 & 95.5 & 97.6 & 95.7 \\
\hline 3 & 95.5 & 96.1 & 95.6 & 95.5 & 95.9 \\
\hline 4 & 96.2 & 95.5 & 95.5 & 96.2 & 95.5 \\
\hline 5 & 95.6 & 95.7 & 96.9 & 103 & 97.2 \\
\hline 6 & 96.3 & 95.5 & 103 & 95.5 & 96.5 \\
\hline AVG & 109.43 & 96.88 & 97.00 & 98.47 & 96.05 \\
\hline SD & 19.51 & 2.74 & 2.73 & 3.28 & 0.62 \\
\hline SE & 7.96 & 1.12 & 1.11 & 1.34 & 0.25 \\
\hline \multicolumn{6}{|c|}{$0.7 \mathrm{~mm}$ mild steel plate specimen } \\
\hline 1 & 111 & 99.1 & 118 & 121 & 96.8 \\
\hline 2 & 121 & 95.5 & 111 & 116 & 95.5 \\
\hline 3 & 111 & 95.5 & 96.8 & 95.5 & 95.5 \\
\hline 4 & 131 & 95.5 & 95.5 & 111 & 95.5 \\
\hline 5 & 95.5 & 95.5 & 95.5 & 121 & 95.5 \\
\hline 6 & 103 & 94.2 & 95.5 & 111 & 95.7 \\
\hline AVG & 112.08 & 95.88 & 102.05 & 112.58 & 95.75 \\
\hline SD & 11.53 & 1.51 & 9.04 & 8.66 & 0.48 \\
\hline
\end{tabular}


Table 3 to be continued

\begin{tabular}{|c|c|c|c|c|c|}
\hline SE & 4.71 & 0.62 & 3.69 & 3.54 & 0.19 \\
\hline \multicolumn{6}{|c|}{$0.8 \mathrm{~mm}$ mild steel plate specimen } \\
\hline 1 & & 95.5 & 111 & 111 & 126 \\
\hline 2 & 131 & 95.5 & 111 & 95.5 & 121 \\
\hline 3 & 121 & 121 & 103 & 95.5 & 103 \\
\hline 4 & 95.5 & 111 & 111 & 111 & 103 \\
\hline 5 & 111 & 102 & 103 & 95.5 & 103 \\
\hline 6 & 111 & 105 & 103 & 103 & 121 \\
\hline AVG & 113.90 & 105.00 & 107.00 & 101.92 & 112.83 \\
\hline SD & 11.82 & 8.96 & 4.00 & 6.95 & 9.97 \\
\hline SE & 4.82 & 3.66 & 1.63 & 2.84 & 4.07 \\
\hline \multicolumn{6}{|c|}{$0.9 \mathrm{~mm}$ mild steel plate specimen } \\
\hline 1 & 103 & 131 & 95.5 & 121 & 95.5 \\
\hline 2 & 131 & 143 & 95.5 & 112 & 111 \\
\hline 3 & 111 & 103 & 95.5 & 103 & 95.5 \\
\hline 4 & 103 & 103 & 103 & 103 & 95.5 \\
\hline 5 & 103 & 95.5 & 95.5 & 121 & 131 \\
\hline 6 & 111 & 95.5 & 95.5 & 103 & 121 \\
\hline AVG & 110.33 & 111.83 & 96.75 & 110.50 & 108.25 \\
\hline SD & 9.91 & 18.39 & 2.80 & 8.08 & 14.00 \\
\hline SE & 4.05 & 7.51 & 1.14 & 3.30 & 5.71 \\
\hline \multicolumn{6}{|c|}{$1.0 \mathrm{~mm}$ mild steel plate specimen } \\
\hline 1 & 131 & 156 & 131 & 121 & 111 \\
\hline 2 & 143 & 131 & 95.5 & 103 & 143 \\
\hline 3 & 143 & 121 & 101 & 131 & 103 \\
\hline 4 & 95.5 & 131 & 111 & 131 & 111 \\
\hline 5 & 95.5 & 111 & 131 & 95.5 & 121 \\
\hline 6 & 111 & 101 & 132 & 143 & 123 \\
\hline AVG & 119.83 & 125.17 & 116.92 & 120.75 & 118.67 \\
\hline SD & 20.25 & 17.42 & 15.12 & 16.62 & 12.78 \\
\hline SE & 8.27 & 7.11 & 6.17 & 6.79 & 5.22 \\
\hline
\end{tabular}

Table 4 Hardness test on different thicknesses of mild steel plate specimens without welding operation (control).

\begin{tabular}{lllllll}
\hline S/N & \multicolumn{5}{c}{ Specimens } \\
\cline { 2 - 7 } & $0.5 \mathrm{~mm}$ & $0.6 \mathrm{~mm}$ & $0.7 \mathrm{~mm}$ & $0.8 \mathrm{~mm}$ & $0.9 \mathrm{~mm}$ & $1.0 \mathrm{~mm}$ \\
\hline 1 & 116 & 103 & 103 & 97.3 & 95.7 & 97.5 \\
2 & 111 & 96.1 & 95.5 & 97.1 & 95.1 & 95.5 \\
3 & 107 & 95.1 & 94.8 & 96.3 & 95.4 & 96.2 \\
4 & 105.4 & 95.6 & 96.3 & 97.3 & 95.5 & 103.1 \\
5 & 101.2 & 95.7 & 95.8 & 97.1 & 98.5 & 103 \\
6 & 100.1 & 95.5 & 95.2 & 96.3 & 103 & 95.5 \\
$\mathrm{AVG}$ & 106.78 & 96.83 & 96.77 & 96.90 & 97.20 & 98.47 \\
$\mathrm{SD}$ & 5.49 & 2.77 & 2.83 & 0.43 & 2.83 & 3.31 \\
$\mathrm{SE}$ & 2.24 & 1.13 & 1.15 & 0.18 & 1.16 & 1.35 \\
\hline
\end{tabular}




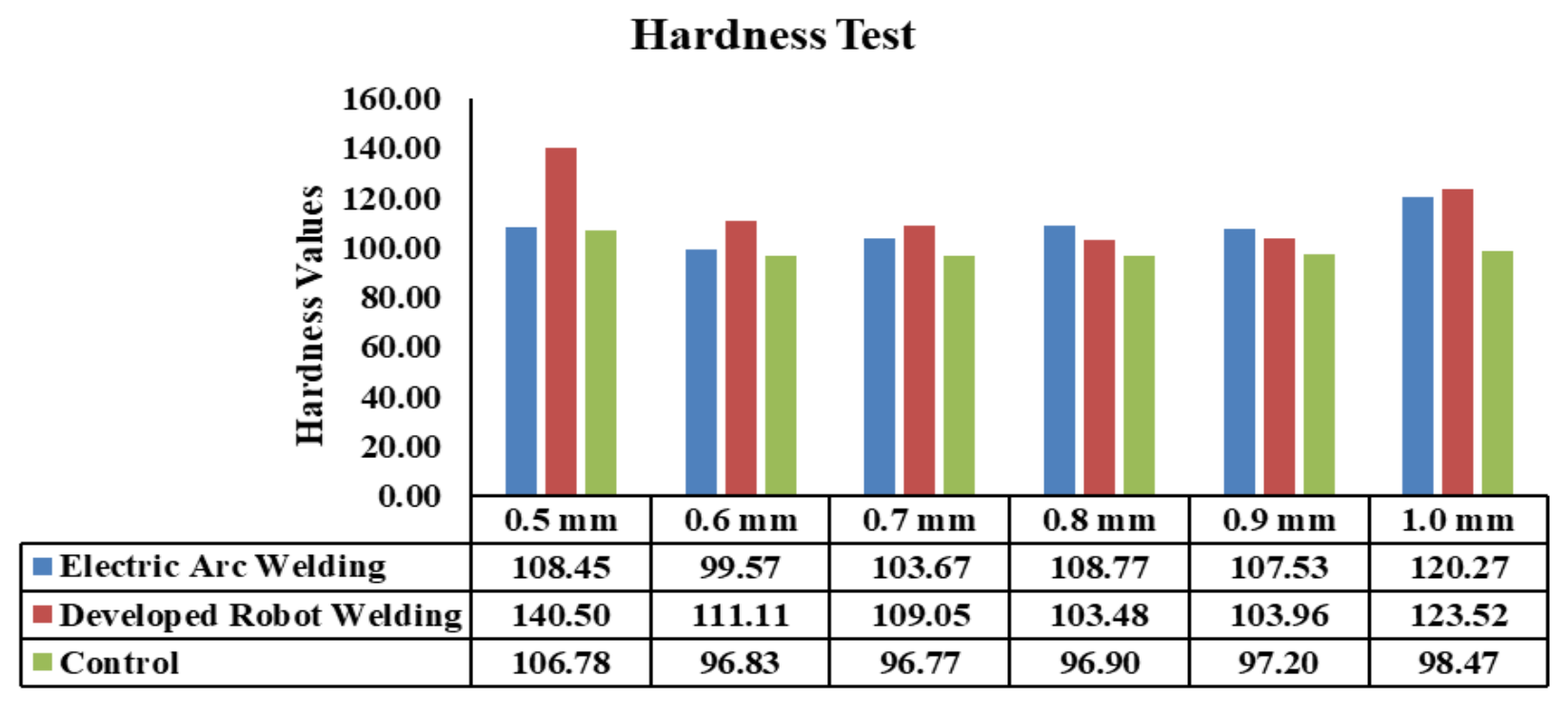

Specimens

Fig. 3 Hardness test of welded and un-welded mild steel plate specimens.

\section{Statistical Analyses Results and Discussion}

The statistical tools adopted in this research include: descriptive statistics, ANOVA analysis, test of homogeneity of Variances and Post Hoc test (Least Significant Differences) while the software deployed for the analysis is Statistical Package of Social Sciences (SPSS version 2016). Tables 5-8 show the statistical analysis of the hardness test of welded and un-welded mild steel plate specimens. Table 5 reveals the descriptive statistics of the hardness test in which the developed robot welding has the highest mean value of 115.30, standard deviation value of 14.32 and variance value of 205.06. Table 6 shows homogeneity of variance among hardness tests of the samples in which the result reveals that there is variation in the hardness test among the tests of the samples since $p$-value is 0.038 . Table 7 shows in the ANOVA test result that there is a significant difference in the hardness of the samples in which developed robot welding operation gave the highest hardness compared with electric arc welding and un-welded (CONTROL) since $p$-value is 0.028 . Table 8 shows the mean difference of 16.48 between developed robot welding and un-welded (CONTROL) samples and 7.26 between developed robot welding and electric arc welding samples.

Tables 9-11 show the statistical analysis of the loads on welded and un-welded mild steel plate specimens. Table 9 reveals the descriptive statistics of the load in which the developed robot welding samples collectively have the lowest mean value of 2,536.85, standard deviation value of 704.21 and variance value of 495,911.72. Table 10 shows homogeneity of variance among loads of the samples in which the result reveals that there is no variation in the loads among the tests of the samples since $p$-value is 0.322 . Table 11 shows in the ANOVA test result that there is no significant difference in the loads of the samples since $p$-value is 0.51 .

Tables 12-15 show the statistical analysis of the extensions of welded and un-welded mild steel plate specimens. Table 12 reveals the descriptive statistics of the extension in which the developed robot welding samples collectively have the lowest mean value of 1.29 , standard deviation value of 0.43 and variance value of 0.18 . Table 13 shows homogeneity of variance among extensions of the samples in which the result reveals that there is variation in the extensions 
Table 5 Descriptive statistics of the hardness test of the samples.

\begin{tabular}{|c|c|c|c|c|c|c|c|c|c|}
\hline & \multirow[b]{2}{*}{$N$} & \multirow{2}{*}{ Mean } & \multirow{2}{*}{$\begin{array}{l}\text { Std. } \\
\text { deviation }\end{array}$} & \multirow{2}{*}{ Variance } & \multirow{2}{*}{ Std. error } & \multicolumn{2}{|c|}{$\begin{array}{l}\text { 95\% confidence interva } \\
\text { for mean }\end{array}$} & \multirow{2}{*}{ Minimum } & \multirow{2}{*}{ Maximum } \\
\hline & & & & & & $\begin{array}{l}\text { Lower } \\
\text { bound }\end{array}$ & $\begin{array}{l}\text { Upper } \\
\text { bound }\end{array}$ & & \\
\hline Control & 6 & 98.83 & 3.95 & 15.60 & 1.61 & 94.68 & 102.97 & 96.77 & 106.78 \\
\hline Electric arc welding & 6 & 108.04 & 6.95 & 48.30 & 2.84 & 100.75 & 115.33 & 99.57 & 120.27 \\
\hline Developed robot welding & 6 & 115.30 & 14.32 & 205.06 & 5.85 & 100.28 & 130.33 & 103.48 & 140.50 \\
\hline Total & 18 & 107.39 & 11.28 & 127.24 & 2.66 & 101.78 & 112.99 & 96.77 & 140.50 \\
\hline
\end{tabular}

Table 6 Test of homogeneity of variances among hardness tests of the samples.

\begin{tabular}{llll}
\hline Levene statistic & df1 & df2 & Sig. $(p$-value $)$ \\
\hline 4.099 & 2 & 15 & 0.038 \\
\hline
\end{tabular}

Table 7 ANOVA test of the hardness test of the samples.

\begin{tabular}{lllllll}
\hline & Sum of squares & $\mathrm{df}$ & Mean square & F calc. & Sig. $(p$-value $)$ & $F$ critical \\
\hline Between groups & 818.43 & 2 & 409.21 & 4.57 & 0.028 & 3.68 \\
Within groups & $1,344.41$ & 15 & 89.63 & & & \\
Total & $2,162.84$ & 17 & & & & \\
\hline
\end{tabular}

Table 8 Post hoc test: least significant differences (LSD) for hardness test multiple comparisons between the samples.

\begin{tabular}{|c|c|c|c|c|c|c|}
\hline \multirow{2}{*}{ (I) Samples } & \multirow{2}{*}{ (J) Samples } & \multirow{2}{*}{$\begin{array}{l}\text { Mean } \\
\text { difference (I-J) }\end{array}$} & \multirow{2}{*}{ Std. error } & \multirow{2}{*}{$\begin{array}{l}\text { Sig. } \\
(p \text {-value) }\end{array}$} & \multicolumn{2}{|c|}{$\begin{array}{l}\text { 95\% confidence interval } \\
\text { for mean }\end{array}$} \\
\hline & & & & & $\begin{array}{l}\text { Lower } \\
\text { bound }\end{array}$ & $\begin{array}{l}\text { Upper } \\
\text { bound }\end{array}$ \\
\hline \multirow[t]{2}{*}{ Control } & Electric arc welding & -9.22 & 5.47 & 0.112 & -20.87 & 2.43 \\
\hline & Developed robot welding & $-16.48 *$ & 5.47 & 0.009 & -28.13 & -4.82 \\
\hline \multirow[t]{2}{*}{ Electric arc welding } & Control & 9.22 & 5.47 & 0.112 & -2.43 & 20.87 \\
\hline & Developed robot welding & -7.26 & 5.47 & 0.204 & -18.91 & 4.39 \\
\hline \multirow[t]{2}{*}{ Developed robot welding } & Control & $16.48^{*}$ & 5.47 & 0.009 & 4.83 & 28.13 \\
\hline & Electric arc welding & 7.26 & 5.47 & 0.204 & -4.39 & 18.91 \\
\hline
\end{tabular}

Table 9 Descriptive statistics of the load of the samples.

\begin{tabular}{|c|c|c|c|c|c|c|c|c|c|}
\hline & \multirow{2}{*}{$N$} & \multirow{2}{*}{ Mean } & \multirow{2}{*}{$\begin{array}{l}\text { Std. } \\
\text { deviation }\end{array}$} & \multirow{2}{*}{ Variance } & \multirow{2}{*}{$\begin{array}{l}\text { Std. } \\
\text { error }\end{array}$} & \multicolumn{2}{|c|}{$\begin{array}{c}\text { 95\% confidence } \\
\text { interval for mean }\end{array}$} & \multirow{2}{*}{ Minimum } & \multirow{2}{*}{ Maximum } \\
\hline & & & & & & $\begin{array}{l}\text { Lower } \\
\text { bound }\end{array}$ & $\begin{array}{l}\text { Upper } \\
\text { bound }\end{array}$ & & \\
\hline Control & 6 & $3,219.71$ & $1,224.92$ & $1,500,429.01$ & 500.07 & $1,934.23$ & $4,505.18$ & $1,595.28$ & $4,863.80$ \\
\hline Electric arc welding & 6 & $2,665.37$ & $1,159.50$ & $1,344,440.25$ & 473.36 & $1,448.54$ & 3,882.19 & $1,119.70$ & $4,195.03$ \\
\hline Developed robot welding & 6 & $2,536.85$ & 704.21 & $495,911.72$ & 287.49 & $1,797.83$ & 3,275.86 & $1,372.94$ & $3,188.31$ \\
\hline Total & 18 & $2,807.31$ & $1,037.08$ & $1,075,534.93$ & 244.44 & $2,291.58$ & 3,323.03 & $1,119.70$ & $4,863.80$ \\
\hline
\end{tabular}

Table 10 Test of homogeneity of variances among load of the samples.

\begin{tabular}{llll}
\hline Levene statistic & df1 & df2 & Sig. $(p$-value $)$ \\
\hline 1.222 & 2 & 15 & 0.322 \\
\hline
\end{tabular}

Table 11 ANOVA test of the load of the samples.

\begin{tabular}{lllllll}
\hline & Sum of squares & df & Mean square & F calc. & Sig. $(p$-value $)$ & $F$ critical \\
\hline Between groups & $1,580,216.01$ & 2 & $790,108.006$ & 0.71 & 0.51 & 3.68 \\
Within groups & $16,703,927.28$ & 15 & $1,113,595.83$ & & & \\
Total & $18,284,145.28$ & 17 & & & & \\
\hline
\end{tabular}


Table 12 Descriptive statistics of the extension of the samples.

\begin{tabular}{|c|c|c|c|c|c|c|c|c|c|}
\hline & \multirow{2}{*}{$N$} & \multirow{2}{*}{ Mean } & \multirow{2}{*}{$\begin{array}{l}\text { Std. } \\
\text { deviation }\end{array}$} & \multirow{2}{*}{ Variance } & \multirow{2}{*}{ Std. error } & \multicolumn{2}{|c|}{$\begin{array}{c}\text { 95\% confidence } \\
\text { interval for mean }\end{array}$} & \multirow{2}{*}{-Minimum } & \multirow{2}{*}{ Maximum } \\
\hline & & & & & & $\begin{array}{l}\text { Lower } \\
\text { bound }\end{array}$ & $\begin{array}{l}\text { Upper } \\
\text { bound }\end{array}$ & & \\
\hline Control & 6 & 6.57 & 2.50 & 6.25 & 1.02 & 3.95 & 9.19 & 2.87 & 9.87 \\
\hline Electric arc welding & 6 & 2.51 & 0.97 & 0.94 & 0.40 & 1.48 & 3.53 & 1.51 & 4.27 \\
\hline Developed robot welding & 6 & 1.29 & 0.43 & 0.18 & 0.18 & 0.83 & 1.74 & 0.67 & 1.85 \\
\hline Total & 18 & 3.45 & 2.75 & 7.56 & 0.65 & 2.08 & 4.82 & 0.67 & 9.87 \\
\hline
\end{tabular}

Table 13 Test of homogeneity of variances among extension of the samples.

\begin{tabular}{llll}
\hline Levene statistic & df1 & df2 & Sig. $(p$-value $)$ \\
\hline 6.224 & 2 & 15 & 0.011 \\
\hline
\end{tabular}

Table 14 ANOVA test of the extension of the samples.

\begin{tabular}{lllllll}
\hline & Sum of squares & df & Mean square & F calc. & Sig. $(p$-value $)$ & $F$ critical \\
\hline Between groups & 91.83 & 2 & 45.91 & 18.70 & 0.001 & 3.68 \\
Within groups & 36.83 & 15 & 2.46 & & & \\
Total & 128.66 & 17 & & & & \\
\hline
\end{tabular}

Table 15 Post hoc test: least significant differences (LSD) for extension multiple comparisons between the samples.

\begin{tabular}{|c|c|c|c|c|c|c|}
\hline \multirow{2}{*}{ (I) Samples } & \multirow{2}{*}{ (J) Samples } & \multirow{2}{*}{$\begin{array}{l}\text { Mean } \\
\text { difference } \\
(\mathrm{I}-\mathrm{J})\end{array}$} & \multirow{2}{*}{ Std. error } & \multirow{2}{*}{$\begin{array}{l}\text { Sig. } \\
\text { ( } p \text {-value) }\end{array}$} & \multicolumn{2}{|c|}{$\begin{array}{l}\text { 95\% confidence } \\
\text { interval for mean }\end{array}$} \\
\hline & & & & & $\begin{array}{l}\text { Lower } \\
\text { bound }\end{array}$ & $\begin{array}{l}\text { Upper } \\
\text { bound }\end{array}$ \\
\hline \multirow[t]{2}{*}{ Control } & Electric arc welding & 4.06* & 0.90 & 0.001 & 2.14 & 5.99 \\
\hline & Developed robot welding & $5.28 *$ & 0.90 & 0.001 & 3.36 & 7.21 \\
\hline \multirow[t]{2}{*}{ Electric arc welding } & Control & $-4.06^{*}$ & 0.90 & 0.001 & -5.99 & -2.14 \\
\hline & Developed robot welding & 1.22 & 0.90 & 0.197 & -0.71 & 3.15 \\
\hline \multirow[t]{2}{*}{ Developed robot welding } & Control & $-5.28 *$ & 0.90 & 0.001 & -7.21 & -3.36 \\
\hline & Electric arc welding & -1.22 & 0.90 & 0.197 & -3.15 & 0.71 \\
\hline
\end{tabular}

among the tests of the samples since $p$-value is 0.011 . Table 14 shows in the ANOVA test result that there is a significant difference in the extension of the samples in which developed robot welding operation gave the lowest extension compared with electric arc welding and un-welded (CONTROL) since $p$-value is 0.001 . Table 15 shows the mean difference of -5.28 between developed robot welding and un-welded (CONTROL) samples and -1.22 between developed robot welding and electric arc welding samples.

\section{Conclusion}

The statistical analysis of hardness tests for developed welding robot, manual electric arc welding and un-welded (control) mild steel plates of different thicknesses was carried out. The results revealed that the developed robot welding has the highest mean value of 115.30, standard deviation value of 14.32 and variance value of 205.06. The results equally showed homogeneity of variance among hardness tests of the samples, which implies variation in the hardness test among the tests of the samples since $p$-value is 0.038 . The ANOVA test result revealed that there is a significant difference in the hardness of the samples in which developed robot welding operation gave the highest hardness compared with electric arc welding and un-welded (CONTROL) since p-value is 0.028 . The results also showed the mean difference of 16.48 between developed robot welding and un-welded (CONTROL) samples and 7.26 between developed robot welding and electric arc welding samples.

The descriptive statistics of the load showed that 
the developed robot welding samples collectively have the lowest mean value of 2,536.85, standard deviation value of 704.21 and variance value of 495,911.72. It further shows homogeneity of variance among loads of the samples in which the result reveals that there is no variation in the loads among the tests of the samples since $p$-value is 0.322 . The ANOVA test result for load revealed that there is no significant difference in the loads of the samples since $p$-value is 0.51 . The descriptive statistics of the extension in which the developed robot welding samples collectively have the lowest mean value of 1.29, standard deviation value of 0.43 and variance value of 0.18 were also determined. The results also showed homogeneity of variance among extensions of the samples in which it revealed that there is variation in the extensions among the tests of the samples since $p$-value is 0.011. The ANOVA test result of the extension shows that there is a significant difference in the extension of the samples in which developed robot welding operation gave the lowest extension compared with electric arc welding and un-welded (CONTROL) since $p$-value is 0.001 . Finally, the mean differences of -5.28 between developed robot welding and un-welded (CONTROL) samples and -1.22 between developed robot welding and electric arc welding samples were established.

\section{References}

[1] Winters, R., Winters, A., and Amedee, R. G. 2010. “Statistics: A Brief Overview.” Ochsner J 10: 213-6.

[2] Sprent, P. 2003. "Statistics in Medical Research.” Swiss Med Weekly 133: 522-9.

[3] Kaur, S. P. 2013. "Variables in Research.” Indian J Res Rep Med Sci 4: 36-8.
[4] Missori, S., and Koerber, C. 1997. "Laser Beam Welding of Austenitic-Ferritic Transition Joints.” Weld J 76 (3): 125-34.

[5] Lundin, C. D. 1982. "Dissimilar Metal Welds-Literature Review.” Weld J 61 (2): 58s-63s.

[6] Jariyabon, M., Davenport, A. J., Ambert, R., Connolly, B. J., Willians, S. W., and Price, D. A. 2007. "The Effect of Welding Parameters on the Corrosion Behaviour of Friction Stir Welded AA2024-T351." Corrosion Sci. 49: 877-909.

[7] Lothongkum, G., Viyanit, E., and Bhandhubanyong, P. 2001. "Study on the Effects of Pulsed TIG Welding Parameters on Deltaferrite Content, Shape Factor and Bead Quality in Orbital Welding of AISI 316L Stainless Steel Plate.” J. Mater. Proc. Technol. 110: 233-8.

[8] Lothongkum, G., Chaoumbai, P., and Bhandhubanyong, P. 1999. "TIG Pulse Welding of the 304L Stainless Steel in Flat, Vertical and Overhead Positions.” J. Mater. Process Technol. 8 (6): 410-7.

[9] Karadeniz, E., Ozsarac, U., and Yildiz, C. 2007. “The Effect of Process Parameters on Penetration in Gas Metal Arc Welding Processes.” Mater. Design 28: 649-56.

[10] Armentani, E., Esposito, R., and Sepe, R. 2007. “The Effect of Thermal Properties and Weld Efficiency on Residual Stresses in Welding." Journal of Achievements in Materials and Manufacturing Engineering 20: 319-22.

[11] Mohammed, R. A., Abdulwahab, M., and Dauda, E. T. 2013. "Properties Evaluation of Shielded Metal Arc Welded Medium Carbon Steel Material.” International Journal of Innovative Research in Science, Engineering and Technology 2 (8): 3351-7.

[12] Talabi, S. I., Owolabi, O. B., Adebisi, J. A., and Yahaya, T. 2014. "Effect of Welding Variables on Mechanical Properties of Low Carbon Steel Welded Joint.” Advances in Production Engineering \& Management 9 (4): 181-6.

[13] Oladebeye, D. H., Adejuyigbe, S. B., and Ayodeji, S. P. 2020. "Comparative Analysis of Mechanical Properties of Mild Steel Plates Welded with the Developed Welding Robot and Manual Electric Arc Welding.” International Journal of Engineering Development and Research 8 (2): 289-302. 